\title{
MECHANISM OF TILL DEPOSITION RELATED TO THERMAL CONDITIONS IN A PLEISTOCENE GLACIER
}

\author{
By John SHaw \\ (Department of Geography, University of Alberta, Edmonton 7, Alberta, Canada)
}

\begin{abstract}
A record of sedimentation from pro-glacial sandur deposits through pro-glacial lake deposits to final deposition of till is used to interpret changing environmental conditions, and depositional processes, during the development of the "Little Welsh Advance" in the Shrewsbury area, England. The relationship between lacustrine sediments and till establishes till deposition by flowage. However, the most important conclusions are derived from the deduction that lacustrine sediments were incorporated into the basal part of the ice sheet and transported across previously deposited end moraines. A discussion of this deduction, based on the findings of Weertman ( 1961 ), establishes that during the advancing phase the ice sheet was of the polar type. Final melting is thought to have occurred by both top-melt and under-melt as a result of climatic amelioration.
\end{abstract}

RÉsumé. Mécanismes des dépôts de "till" en relation avec les conditions thermiques dans un glacier pléistocène. On étudie les sédiments provenant d'un glacier d'épandage proglaciaire, ayant transité sous forme d'alluvions de lac proglaciaire pour former finalement un dépôt de "till" sous-glaciaire. On utilise ces données pour interpréter les changements des conditions d'environnement et les processus de dépôt au moment où s'est produite la "Little Welsh Advance" dans la région de Shrewsbury, Angleterre. La relation entre des sédiments lacustres et le "till" prouve que le dépôt du till s'est effectué dans l'eau. Cependant, les plus importantes conséquences sont tirées de la conclusion selon laquelle les sédiments lacustres se sont trouvés incorporés à la base de la calotte glaciaire et transportés à travers une moraine terminale déposée antèrieurement. Une discussion de cette conclusion, basée sur les travaux de Weertman (1961), établit que, pendant sa phase d'avancée, la calotte était de type polaire. On pense que la fusion finale s'est produite à la fois par en-dessus et par en-dessous à la suite d'une amélioration du climat.

Zusammenfassung. Der Mechanismus der Geschiebeablagerung in Abhängigkeit von den thermischen Bedingungen in einem pleistozänen Gletscher. Die Sedimentfolge im Gletschervorfeld von Sanderaufschüttungen über Seeablagerungen bis hin zur endgültigen Geschiebeablagerung wird zur Interpretation der wechselnden Umweltbedingungen und der Ablagerungsprozesse während der Entwicklung des "Little Welsh Advance" im Gebiet von Shrewsbury, England, herangezogen. Die Beziehungen zwischen den Seeablagerungen und den Geschieben beweisen deren Ablagerung durch Fliessvorgänge. Die wichtigsten Schlüsse werden jedoch aus der Folgerung hergeleitet, dass Seeablagerungen im bodennahen Teil des Eiskörpers eingeschlossen waren und über vorher aufgebaute Endmoränen hinweg transportiert wurden. Eine Diskussion dieser Folgerung, die sich auf die Feststellungen von Weertman (I96I) gründet, beweist, dass der Eisschild während der Vorstossphase vom polaren Typ war. Das endgültige Abschmelzen wird durch Schmelzvorgänge sowohl an der Oberfläche wie an der Unterseite infolge einer Erwärmung des Klimas erklärt.

\section{INTRODUCTION}

In the absence of organic remains, climatic and environmental statements based on the interpretation of glacial deposits are usually quite general. Such statements are limited to an acknowledgement of cold conditions at the time of deposition of glacial till. More informative statements on environmental conditions, depositional process and the thermal properties of past ice sheets are limited by the low preservation potential and exposure of instructive deposits. This paper examines a particular suite of glacigenic deposits yielding information on the depositional environment and the processes of glacial incorporation and sedimentation of detritus. The results are used to reconstruct changing thermal conditions within a past ice sheet. The sedimentary observations were carried out between ig66 and 1969, and are restricted to one site, the gravel pit at Mousecroft Lane, situated I.6 km south-west of Shrewsbury, England (Fig. I). There is general agreement that the lithological succession at the Mousecroft Lane site (Fig. 2) is till overlying sands and gravels, which in turn overlie a second suite of glacigenic sediment. The lower glacigenic suite has diamicton overl ing sands and gravels. The materials in the lower suite are either local or northern and are considered to have been deposited from a glacier which advanced from the Irish Sea area to the north. 


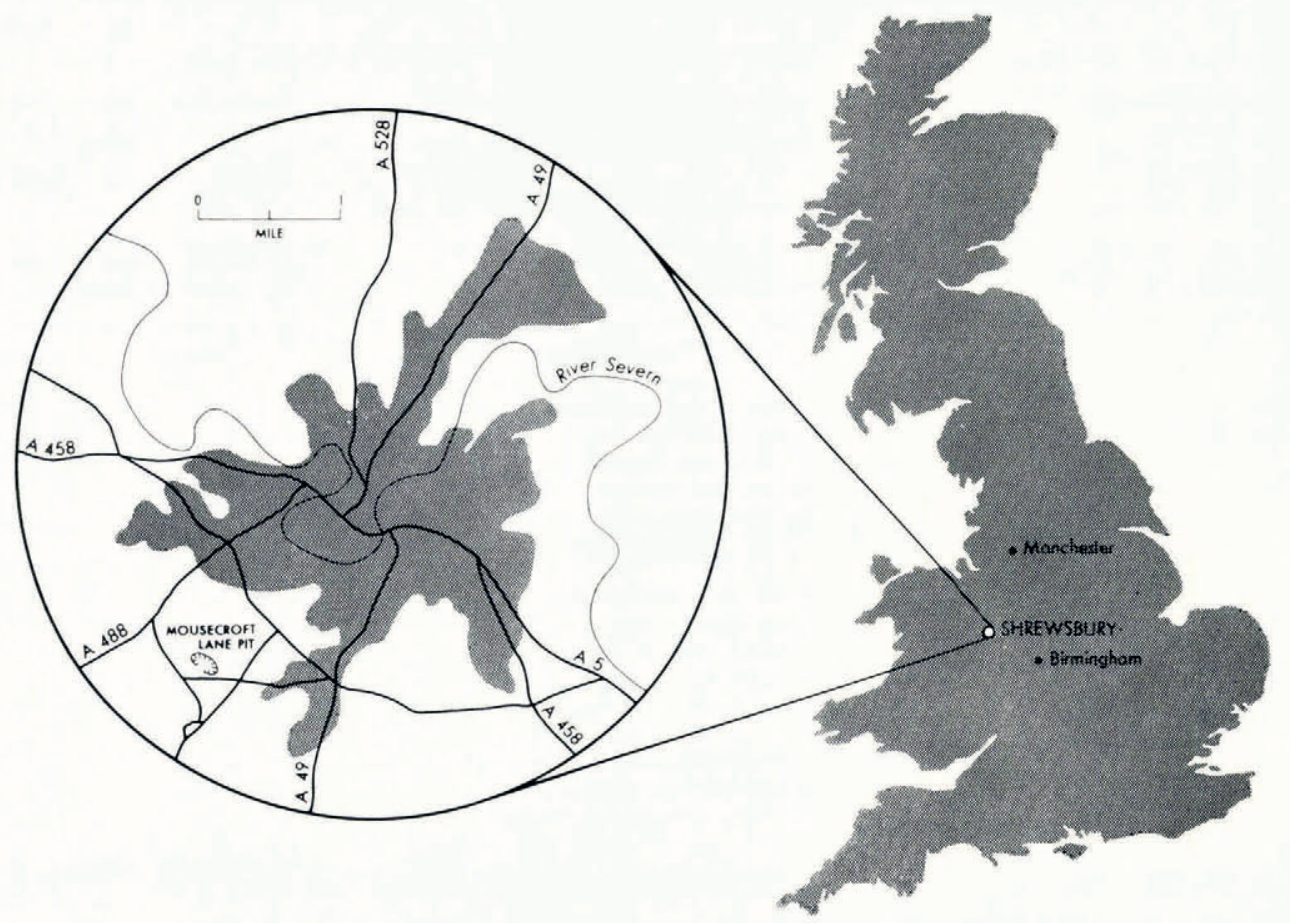

Fig. I. Map of Great Brilain with inset showing the position of the study site near Shrewsbury.

The upper till and sands and gravels are primarily of Welsh origin (Pocock and others, 1938). Although Poole and Whiteman (196I) have stressed the presence of northern erratics within the gravels, they were almost certainly deposited in a pro-glacial braided stream complex by melt waters from the advancing Welsh ice (Pocock and others, 1938; Shaw, unpublished).

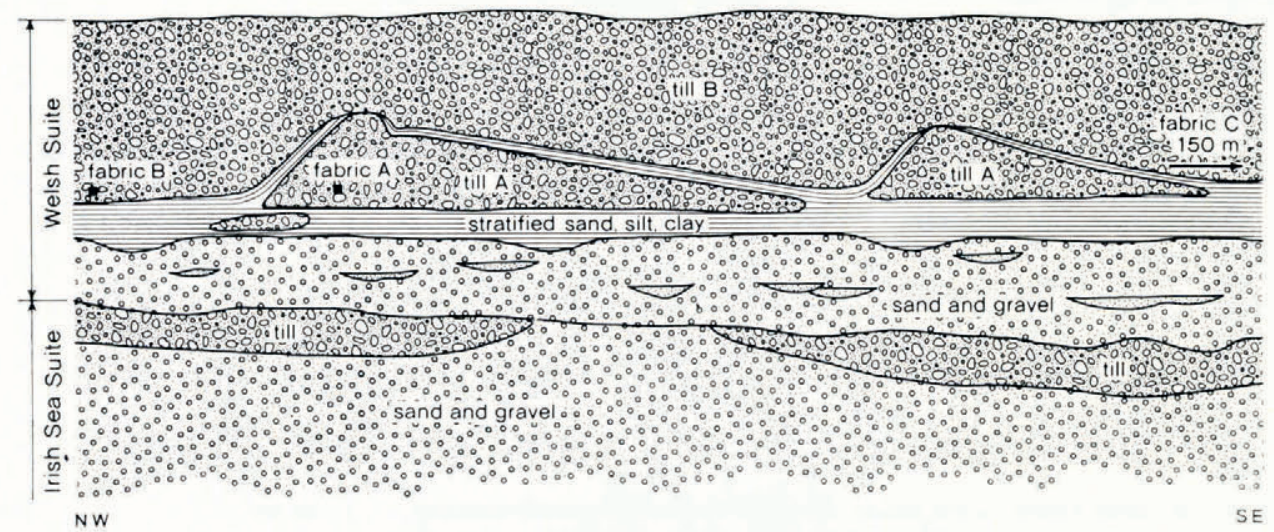

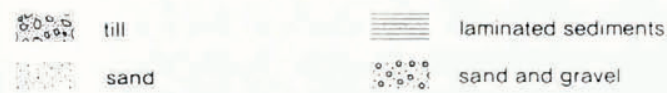

Fig. 2. Stratigraphical succession; Mousecroft Lane, near Shrewsbury, England. 
Although Shotton ( 1962 ) described the diamicton above the lower sands and gravels as being of lacustrine origin, and Poole and Whiteman (1961, p. 107) were rather non-commital about its origin, grouping it in the "Middle Sands", the texture, fabric and abundance of striated stones in this material leave little doubt that the diamicton is in fact a till (Shaw, unpublished). The underlying sands and gravels have been shown to be ice-contact sediments, and were most probably deposited from the same ice sheet as the overlying till (Shaw, unpublished).

The deposits of Welsh origin, the upper till and the directly underlying sands and gravels, have been allocated to the "Little Welsh Advance" (Wills, 1950). The Irish Sea suite is most probably a correlative of the Irish Sea till at Four Ashes which has been shown to be post-Upton Warren interstadial complex and, therefore, of late Weichselian age (Shotton, 1967). In the absence of absolute dating, it can only be stated that the "Little Welsh glaciation" marks a local ice advance post-dating the main late Weichselian Irish Sea glaciation; sufficient time had elapsed before the advance of the Welsh ice to allow the general dissipation of the Irish Sea ice sheet in the Shrewsbury area. However, it is important to note that large bodies of Irish Sea ice became buried below both Irish Sea and Welsh sediments. The final melting of these ice blocks caused faulting and slumping of both suites of deposits (Shaw, unpublished).

The ice limit of the "Little Welsh Advance" has yet to be defined, although it is believed to have been close to the present site of Shrewsbury (Wills, I950; Peake, I96 I; Poole and Whiteman, I96r).

The observations and deductions which follow are related to the deposits of the "Little Welsh Advance". The final conclusions, therefore, relate to the characteristics of this advance.

\section{Tills and Associated Deposits}

The till and stratified sand, silt and clay of the "Little Welsh Advance" will now be examined in detail. The gravels which they overlie were laid down by melt waters from the advancing "Little Welsh" ice sheet.

\section{External form}

In the Shrewsbury area there is no distinct terminal moraine to the Little Welsh Advance. Despite the presence of end-moraine features, the topography consists largely of irregularly spaced undulations. Shallow exploration holes in the Shrewsbury area indicate that the till is widespread and, other than in areas of fluvial excavation, it forms the surface deposit. Till thicknesses at Mousecroft Lane vary between 3 and $8 \mathrm{~m}$.

\section{Internal sedimentary structure}

The internal structure of the upper till and stratified deposits may be subdivided into three interdigitational sediment types which are generally conformable with the underlying gravels.

Stratified deposits. These are composed of coarse sand, sand, silt and clay which occur conformably in channels, and above imbrication surfaces developed in the outwash gravels. In the lower sections of these deposits small-scale trough cross-laminated sands are predominant, but at higher levels laminated silts dominate (Fig. 3). Microscope examination of thin sections from the laminated silts reveals that the laminae $\left(0.5^{-1} \mathrm{~mm}\right.$ thick) are graded. Individual laminae show a textural range from silt at the base to clay at the top. Occasional sand laminae and lenses, with a maximum thickness of $3 \mathrm{~mm}$, are found within the higher parallel-bedded sediments. Small-scale collapse structures occur in the gravels and stratified deposits, but they involve only the lower part of the overlying till. 
Till lenses and sheets. Diamicton lenses intimately associated with the stratified deposits occur below the main till. The presence of striated and facetted stones, together with the unsorted nature of these bodies, indicates that the lenses are in fact of till. The contacts between the till lenses and sheets and stratified deposits are of three types:

i. Conformable: this type of contact is restricted to thin till beds $3^{-20} \mathrm{~cm}$ in thickness. Till beds of this nature are illustrated above the scale in Figure 4 .

ii. Interdigitational: the contact between till lenses and laminated sediments is commonly interdigitational as shown to the left of the scale in Figure 4.

iii. Erosional: large till lenses often show erosional contacts at their bases.

In several cases combinations of the erosional and interdigitational contacts occur.

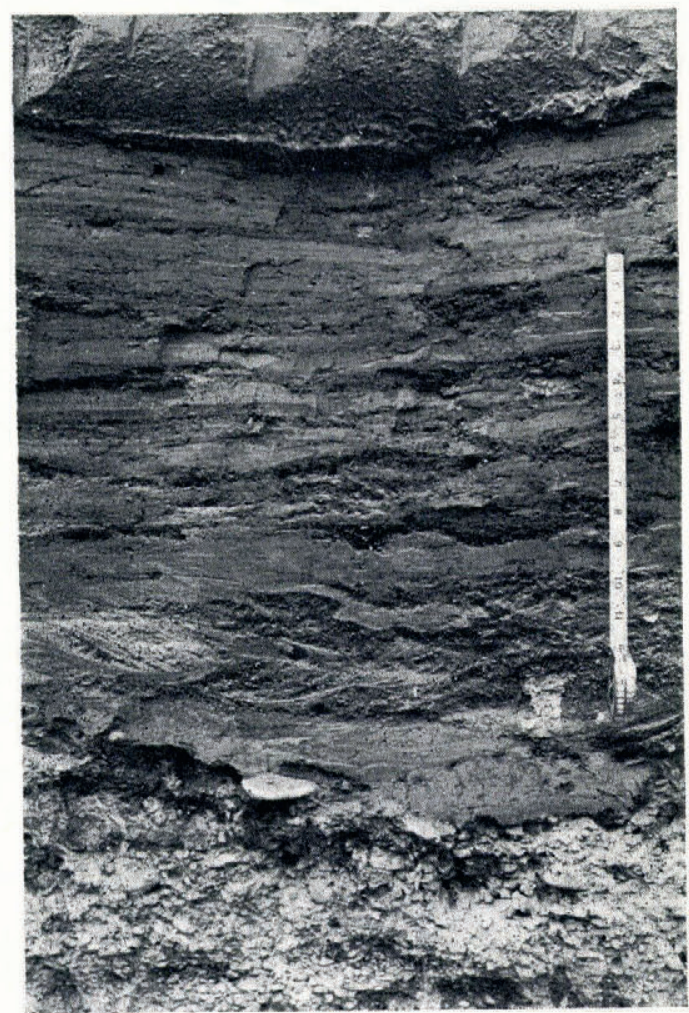

Fig. 3. Stratified sediment underlying till. Note the ripple cross-stratification above the gravels and parallel stratification at higher levels. Scale in inches.

Main till body. The main till body shows a characteristic undulating upper surface and it has a thickness of about $4 \mathrm{~m}$. The most striking internal feature is the presence of two large bodies of till enclosed by stratified deposits (Fig. 2). The north-western of these two structures is illustrated in Figure 5; it has a length of $14.02 \mathrm{~m}$ and a maximum height of $1.93 \mathrm{~m}$. The two structures are only seen along a north-west to south-east trending quarry face; in each case there is a steep north-west slope $\left(\operatorname{dip} 50^{\circ}\right.$ ) and a more gentle south-eastern slope (dip $5^{-10^{\circ}}$ ). Although only two structures were observed, the similarity of form and orientation indicates that these factors are important in the interpretation of the depositional processes which produced these till bodies. 


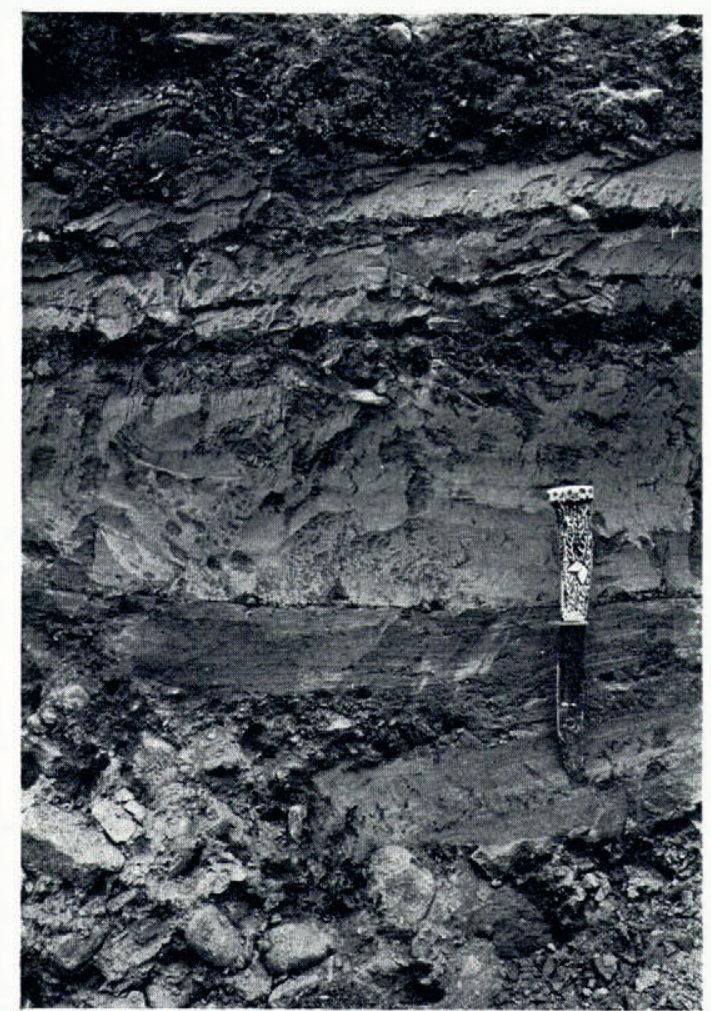

Fig. 4. Stratified sedinent with flow-till lens to left of scale. Interbedded till layers above scale. Scale $28 \mathrm{~cm}$.

Till occurring within the laminated sediments will be referred to as till $\mathrm{A}$, and the body of till outside the laminated sediment as till B (Fig. 2). The texture of these two till bodies is significantly different. Till A contains more stones and sand than till B which has a relatively high clay content. The structural properties of tills A and B confirm the textural contrasts. Columnar structure, which is attributed to soils with a high percentage of colloidal material (Clarke, 1957, p. 75), is characteristic of till B but it is not noted in till A. A certain degree of sorting is found in till A. To the right of the scale in Figure 5 an area of granules

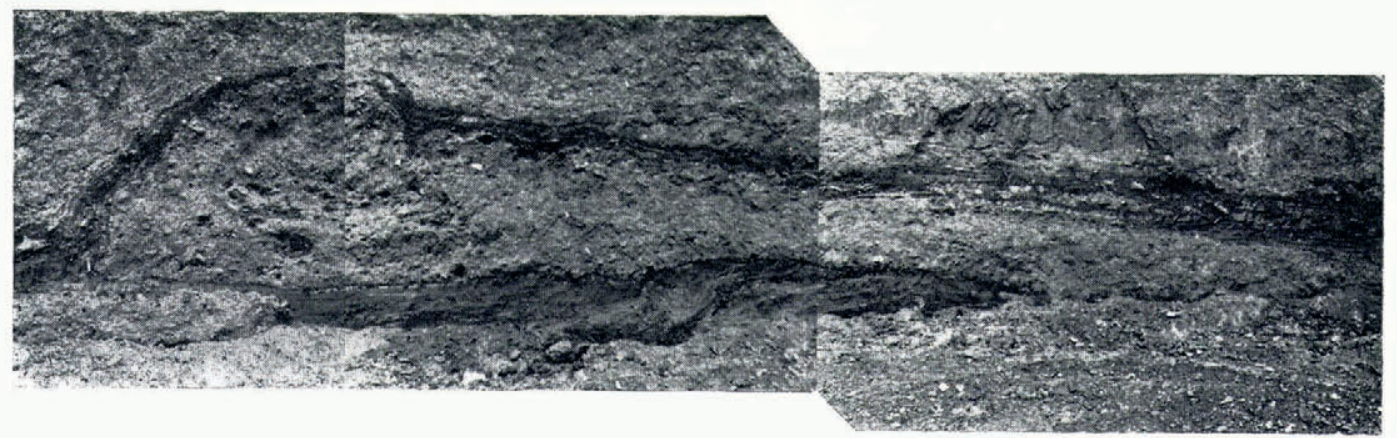

Fig. 5. Laminated sediments overlying till A. Flow-till lens below scale which is situated at the lower left margin of till A. Vote the comparative stoniness of till $A$ and the columnar structure in till $B$. Scale $28 \mathrm{~cm}$. 

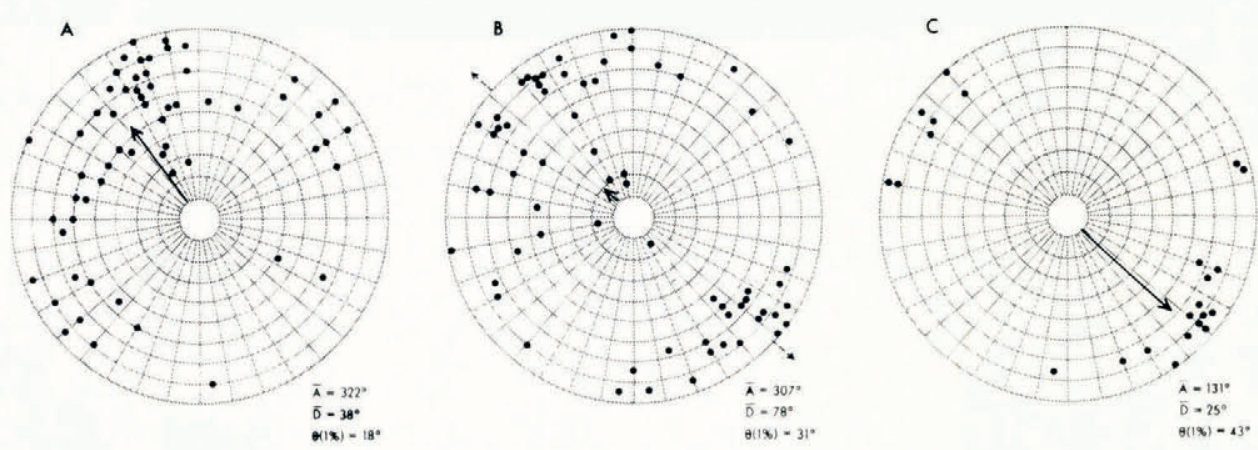

Fig. 6. Amount and direction of dip of long axes of till stones. For measurement locations see Figure 2. Fabric A, $n=60$; fabric $B, n=66$; fabric $C, n=23$.

and small pebbles occurs, and a high concentration of cobbles is to be found at the apex of the structure.

Measurement of the dip and orientation of the long axes of prolate and blade-shaped stones within tills $\mathrm{A}$ and $\mathrm{B}$ (Fig. 2) give vector mean orientations with a range of only $16^{\circ}$ (Fig. 6). The value of $\theta^{\circ} \mathrm{I} \%$ (Steinmetz, I962), which is a measure of the confidence range for the point of balance of a circular distribution, indicates that the point of balance of the fabric distribution in till $\mathrm{A}$ is placed within a much smaller range than is the point of balance for the distributions of till B. Examination of the diagrams (Fig. 6) reveals that this is due to a preferred direction of dip in till A that is not present in till B. In relation to the regional ice

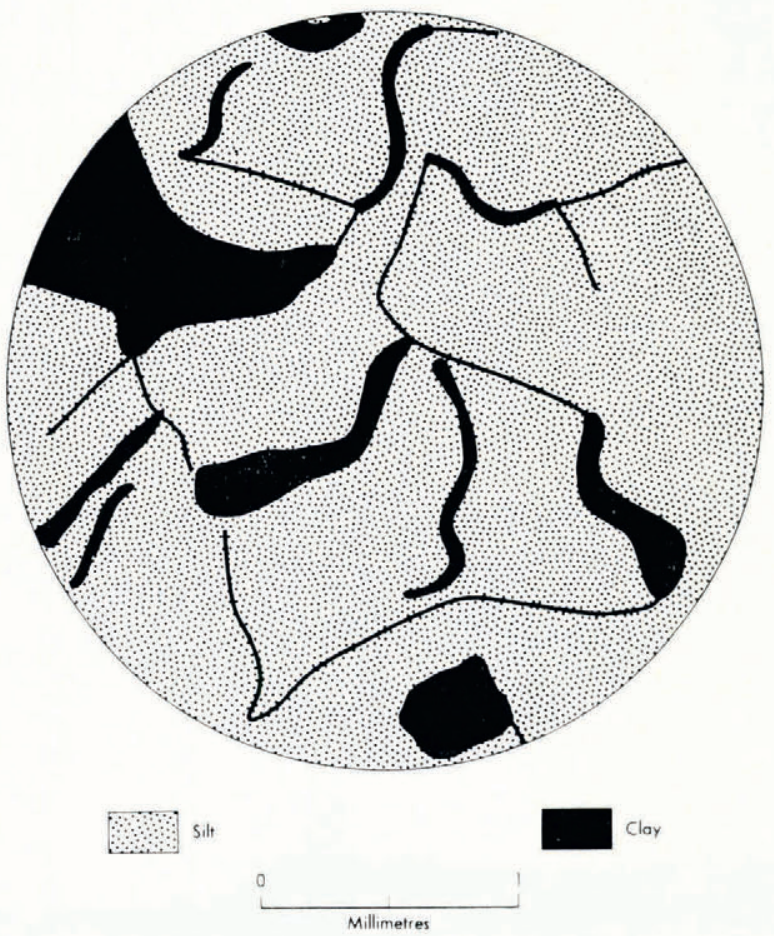

Fig. 7. Brecciated laminated sediment from above till $A$, drawn from projection microscope image. 
movement, which is shown by striae and erratic content of the till to have a strong component from the west, the preferred dip in till $\mathrm{A}$ is up-glacier. In the upper part of till A, above the position of the orientation sample, there is a clearly disturbed fabric with many stones having their long axis or major plane vertical.

The stratified sediments which separate tills A and B (Fig. 5) are superficially identical to those below the till. Individual laminae are continuous and may be traced over till A, dipping at $50^{\circ}$. The major planes of pebbles within the stratified sediments parallel their dip. However, when viewed in thin section some of the fine laminae are seen to exhibit a distinctive brecciated effect, clasts of silt being separated by streaks of clay (Fig. 7).

To the south-east of the north-western body of till A, the laminated sediments are noted to abut against the upper part of till $\mathrm{A}$ in an overstepping sequence (Fig. 5).

\section{Discussion}

The sedimentary properties described may be utilized in the determination of the sequence and nature of the events which occurred during deposition. Basically, this discussion illustrates that the sediments were laid down by an advancing glacier which incorporated lacustrine deposits into the basal ice. The fact of incorporation opens an interesting discussion of the thermal and hydrological characteristics of the former ice sheet.

The generalized succession from gravels, through laminated deposits of gradually lowering flow regime (Harms and Fahnestock, I965), into a complex of till and laminated sediments illustrates an environmental change resulting from ice advance. The gravels are thought to have been deposited in a braided stream environment (Shaw, unpublished). At its up-stream limit, the braided complex was replaced by a pro-glacial lake, into which the laminated sediments were deposited. Very many examples of pro-glacial lakes draining into a braided outwash complex are to be found close to modern glaciers so the above interpretation, based on the sedimentary succession described, appears quite realistic.

The emplacement of the lowermost till lenses and bands marks the first direct sedimentation from the advancing glacier. Conformable and interdigitational contacts between the till and laminated sediments indicate intermittent emplacement of the till into an area of lacustrine suspension sedimentation. Such intermittent emplacement and the presence of erosional contacts suggest that the till lenses and bands were deposited into the pro-glacial lake as flow tills (Boulton, 1968). The lenses and bands described above show similarity with those thought to have been deposited by flowage into a modern fluvio-lacustrine proglacial complex (Boulton, I968, fig. 14).

To this point the events indicate a relatively simple situation with ice advancing over pro-glacial sediment. The thick till deposit which completes the succession is in accord with this hypothesis. However, several elements of the till and its included laminated sediment provide significant information on the incorporation, transport and deposition of debris. The mechanism deduced for the above processes requires certain thermal and hydrological conditions which may therefore be attributed to the ancient ice sheet.

Till A (Fig. 8) rests on laminated lacustrine sediments. To the south-east the lacustrine sediments form a continuous sequence with similar laminated sediments which overstep till A (Fig. 8A). It appears that the till body was deposited into a lake with uninterrupted accumulation of suspension sediment occurring in the south-east, away from the area of till deposition. Winnowing of till A within the lake environment gives a possible explanation for the coarse nature of this till compared with till $\mathrm{B}$.

The exact mode of origin of till $\mathrm{A}$ is uncertain. Either flowage of ablation till (Boulton, I968) or deposition by squeezing of saturated basal till (Hoppe, I952; Andrews and Smithson, I966, p. 287) could have been responsible for the deposition of till A into a frontal lake. The up-glacier dip of prolate stones (Fig. 6A) within the lower part of till A (Fig. 2) may 
support the squeeze hypothesis, but Boulton (1970) has noted the lack of any modern-day verification of this process.

As the laminated sediments overlying till A to the north-west are noted to lie at an angle of $50^{\circ}$ to the horizontal, their direct emplacement from suspension is impossible. However, the steeply dipping laminae do exhibit disturbed graded laminae illustrating primary deposition from suspension, most probably in the frontal lake environment. The frontal origin for till A requires that, for the deposition of till $\mathrm{B}$, glacier over-riding of till A occurred. In order to explain the above characteristics, it is necessary to find some mechanism that allows for the basal incorporation of pro-glacially deposited lacustrine sediments, and their transportation and deposition across an upstanding till body (till A), which was able to maintain its morphological expression.

The ability of till body A to resist horizontal deformation may be explicable in terms of the coarse stony nature of this till, and also by increased strength due to the presence of ground ice. The stony nature of the till would cause dilatant behaviour, distortion requiring expansion and relatively high stress (Smalley and Unwin, I968). Ground ice is most likely to be present during the initial over-riding in a winter advance stage. Later argument will show that the marginal area of the glacier exhibited polar conditions, and therefore the presence of ground ice in till A is strongly favoured. The presence of many almost vertical stones in the upper part of till A is further supporting evidence for frozen ground conditions. Evidently, for till A to have been frozen, the pro-glacial lake must have drained subsequent to the situation illustrated in Figure 8A.

The incorporation of lacustrine sediments into the base of the ice and their subsequent transportation implies that particular thermal and hydrological conditions are met at the glacier base (Weertman, I96I). Figure 8B illustrates the initial conditions with the laminated sediments to be incorporated lying above the $0^{\circ} \mathrm{C}$ isotherm. Up-glacier from this zone, increased thickness and ice velocity combine to produce a zone of basal melting. Migration of melt water from the melting zone will occur down the pressure gradient towards the glacier margin. Consequently, between the two above zones a further zone exists where melt water is frozen to the base of the glacier (Fig. 8C). With ice advance the increase in thickness brings part of the laminated sediment into the zone of basal freezing. The freezing occurs at the $0^{\circ} \mathrm{C}$ isotherm, that is, below the laminated sediments. By this means clean ice is formed below the laminated sediments which are lifted into the glacier and are transported across till A (Fig. 8C and D) as a debris band. The brecciation of the transported laminated sediments (Fig. 7) is believed to have occurred at this stage. Evidently, at this stage the glacier is of the polar type, melt only occurring in restricted zones where excess heat produced by sliding accumulates.

The presence of collapse structures in the laminated sediments and gravels which only involve the lower part of the till is evidence that final till release was at least partly by undermelt. The collapse structures result from the melting out of small ice blocks (about I $\mathrm{m}$ thick). The lower part of till B and the incorporated laminated sediments are thought to have been released and to have filled the pits caused by ice-block melting, hence their deformation. However, the upper part of till B, still frozen within the glacier, was not deposited until the kettle depressions were filled. Evidently, the lower till was released before the upper, illustrating till release by under-melt. The final release of the till is believed to have been a result of surface melt of the ice body. Widespread columnar structure in till B is believed to be a consequence of high clay content and the absence of great vertical pressure which would have resulted if the till had been totally released by under-melt whilst a considerable thickness of ice remained. Clay till released under overlying ice pressure is noted to show horizontal fissile structure (Sitler and Chapman, I955, p. 267). Both the top-melting and the undermelting indicate an ameliorating climate. Initiation of under-melt in the waning stage of a glacier may only occur by increasing surface temperature. Ice thickness and heat produced 
A

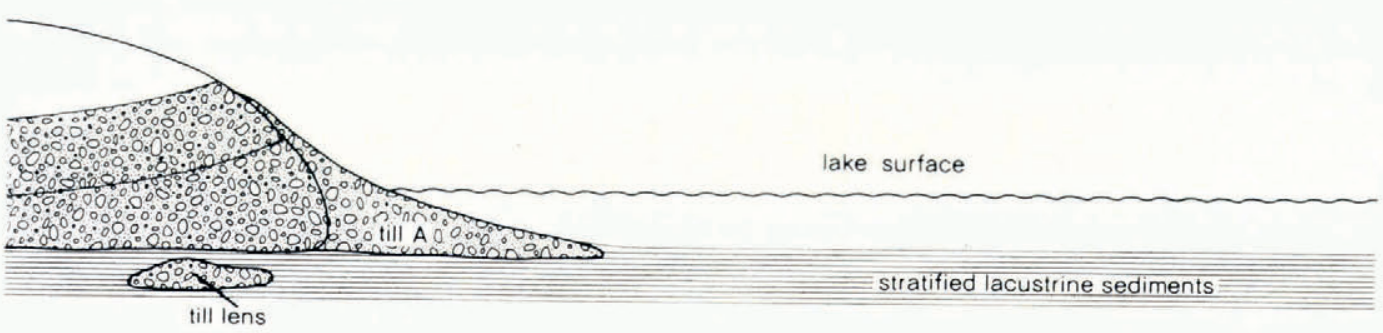

B

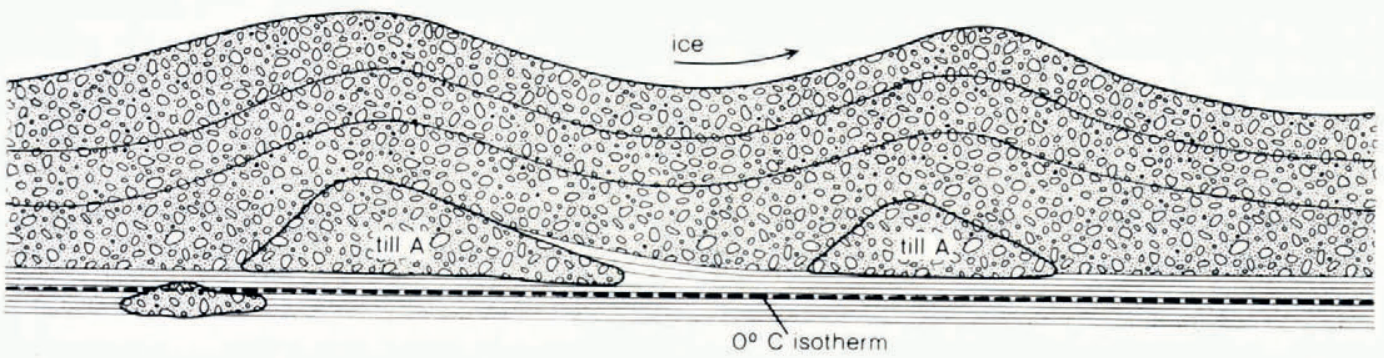

C

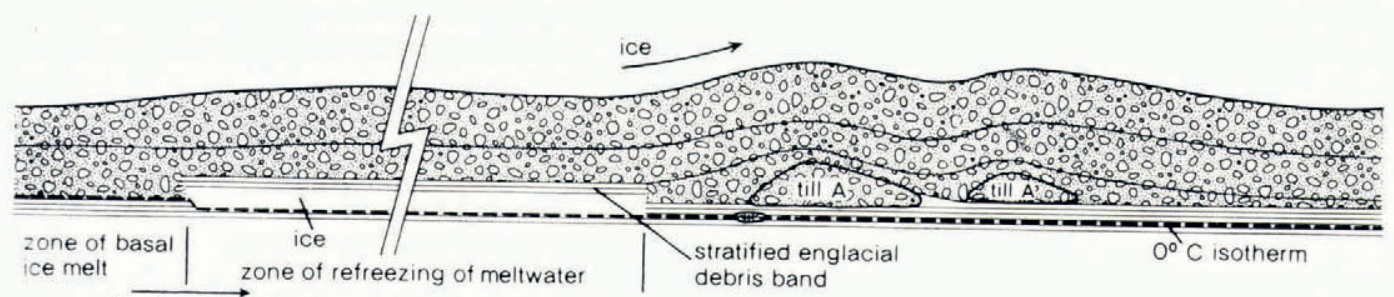

meltwater migration

D

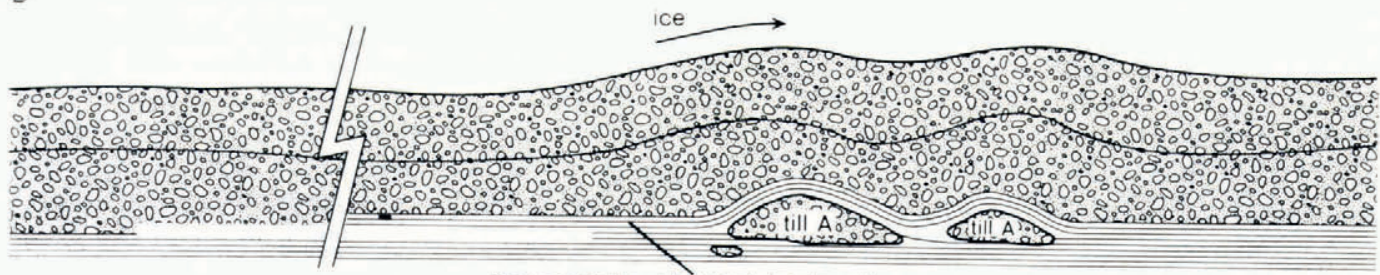

transported englacial debris band

: till

Fig. 8. Deposition of till $A$ and the transportation of till $B$ and stratified sediment across it. Deposition of till $A$ occurs during a period of general advance of a cold-based glacier. Advance carries debris-charged ice across till A. At stage $C$ the increased ice thickness up-glacier from till A caused zones of melting and freezing which lead to the incorporation of stratified sediment into the glacier. Stage D illustrates the transport of the now englacial stratified sediment across till A. Final melt produces the sequence seen in Figure 2. Note there is a major change in scale from stages $A$ and $B$ to stages $C$ and $D$. 
by sliding will evidently be reduced, and therefore an increased basal temperature can only occur by a reduction in the amount of geothermal heat away from the ice base. This must be brought about by an increase in surface temperature. The conclusion to be drawn from the above interpretation of the temperature conditions is that in the initial stage the glacier was of the polar type, sub-freezing temperatures extending throughout the zone below the surface zone of seasonal fluctuation. An up-glacier zone, however, is thought to have exhibited basal melt due to the increased heat supply from sliding and also due to a lower temperature gradient. In the final stage, amelioration of climate is thought to have produced higher surface temperatures, permitting accelerated surface melt and also activating basal melt.

\section{Conclusions}

The till of the "Little Welsh Advance" has been shown to overlie pro-glacial deposits of this advance. Environmentally, the pro-glacial situation was one of a frontal glacial lake into which till flowage and suspension sedimentation occurred. Beyond the glacial lake, the gravels associated with the "Little Welsh Advance" were deposited in a braided stream complex.

Ice-front accumulation of till during advance produced the end-moraine features, till A (Fig. 2). Toward-glacier dip of till stones within till A (Fig. 6A) suggests that the frontal moraines may have accumulated by ice-press squeezing of saturated till into the lake complex. With continuing advance the end moraine features were over-ridden. The ability of these moraines to maintain their morphological expression is explained in terms of their stoniness causing dilatant behaviour under stress and also on account of their probable frozen condition at the time of over-riding.

The laminated sediments which overlie the former end moraines (Fig. 5) are believed to have been incorporated in the ice along a zone of basal freezing of melt water, which lay up-glacier from the moraines. These laminated sediments, which were of primary lacustrine sedimentation, were then transported to a position above the former end moraines (Fig. 8C and D).

The incorporation of the laminated sediments implies that the ice sheet of the "Little Welsh Advance" was of the polar type at the time of incorporation. Melting-point temperatures were only reached in the basal part of this ice sheet in areas where the heat of sliding and the geothermal heat input were not completely conducted to the higher colder ice.

At a later stage, the basal ice of the whole ice sheet reached melting point and the lowermost englacial sediments were deposited by subglacial melt-out. By this means the laminated sediments, which comprised the lowest englacial material, were deposited over the end moraines, till A (Fig. 5). The final melt of the glacier and consequent till release was primarily by top-melt. Both the extensive bottom-melt and the final top-melt illustrate that the final dissipation of the "Little Welsh Advance" ice sheet was caused by climatic amelioration.

The Irish Sea glacial sediments underlying the "Little Welsh Advance" were deposited in the late Weichselian. The "Little Welsh Advance" is shown to represent a cold period which succeeded the amelioration of climate which was responsible for the retreat of the main late Weichselian Irish Sea advance.

\section{Acknowledgements}

I should like to thank Mr E. E. Rogers for permitting access to the exposures. Financial support was provided by the Natural Environment Research Council. Miss Wendy Heyworth and Miss Inge Huemmert did the draughting and $\mathrm{Mr} \mathrm{J}$. Chesterman the photographic work. Dr M. J. Crozier carried out a helpful review of the text. 


\section{REFERENCES}

Andrews, J. T., and Smithson, B. B. 1966. Till fabrics of the cross-valley moraines of north-central Baffin Island, Northwest Territories, Canada. Geological Society of America. Bulletin, Vol. 77, No. 3, p. 271-9o. Boulton, G. S. 1968. Flow tills and related deposits on some Vestspitsbergen glaciers. fournal of Glaciology,
Vol. 7, No. 51, p. 391-412. Boulton, G. S. 1970 . On the origin and transport of englacial debris in Svalbard glaciers. Fournal of Glaciology,
Vol. 9, No. 56, p. $213-29$.

Clarke, G. R. I957. The study of the soil in the field. Fourth edition. Oxford, Clarendon Press.

Harms, J. C., and Fahnestock, R. K. ${ }^{1} 965$. Stratification bed forms and flow phenomena. Society of Economic Palaeontologists and Mineralogists (Tulsa, Oklahoma). Special Publication No. 12, p. 84-1 I5.

Hoppe, G. I952. Hummocky moraine regions with special reference to the interior of Norrbotten. Geografiska Annaler, Årg. 34, Ht. I-2, p. I-72.

Peake, D. S. 1961. Glacial changes in the Alyn River system and their significance in the glaciology of the North Welsh Border. Quarterly Journal of the Geological Society of London, Vol. 1 1 7, No. 467, Pt. 3, p. 335-66.

Pocock, R. W., and others. I938. Shrewsbury district, including the Hanwood coalfields, by R. W. Pocock, T. H. Whitehead, C. B. Wedd and T. Robertson. Great Britain. Memoirs of the Geological Survey. England and Wales. Explanation of Sheet 152 .

Poole, E. G., and Whiteman, A. J. 1961. The glacial drifts of the southern part of the Shropshire-Cheshire Basin. Quarterly Zournal of the Geological Society of London, Vol. 117 , No. 465, Pt. 1, p. 91-1 30.

Shaw, J. Unpublished. Aspects of glacigenic sedimentation, with special reference to the area around Shrewsbury. [Ph.D. thesis. Dept. of Geography, University of Reading, Reading, England, i 969.$]$

Shotton, F. W. 1962. A borehole at Conduit Head, Shrewsbury. Transactions of the Caradoc and Severn Valley Field Club, Vol. 15, p. 1-4.

Shotton, F. W. 1967. Age of the Irish Sea glaciation of the Midlands. Nature, Vol. 215, No. 5108, p. 1366. Sitler, R. F., and Chapman, C. A. 1955 . Microfabrics of till from Ohio and Pennsylvania. Fournal of Sedimentary
Petrology, Vol. 25, No. 4, p. $262-69$.

Smalley, I. J., and Unwin, D. J. 1968. The formation and shape of drumlins and their distribution and orientation in drumlin fields. Fournal of Glaciology, Vol. 7, No. 51, p. 377-90.

Steinmetz, R. 1962. Analysis of vectorial data. Journal of Sedimentary Petrology, Vol. 32, No. 4, p. $801-12$.

Weertman, J. I961. Mechanism for the formation of inner moraines found near the edge of cold ice caps and ice sheets. Fournal of Glaciology, Vol. 3 , No. 30, p. $965^{-78}$.

Wills, L. J. 1950. The palaeogeography of the Midlands. Second edition. Liverpool, University Press of Liverpool. 